\title{
PCaPC 圧着工法による「組立 DESIGN OF THE BUILDING USING 箱構造」の建築物の設計 \\ CONSTRUCTION METHOD OF ASSEMBLED PRECAST MEMBERS BY PRESTRESSING
}

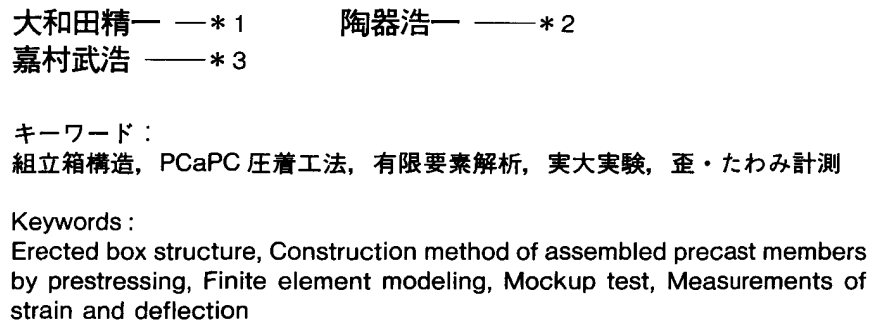

Erected box structure, Construction method of assembled precast members by prestressing, Finite element modeling, Mockup test, Measurements of strain and deflection

Selichi OWADA $-* 1$
Takehiro KAMURA $-* 3$

This paper presents the structural design of a museum constructed with "box assembling structure" for which the PCaPC compression joint method is adopted. All walls, roofs and floors are of precast concrete slabs; the exhibition spaces were made by erecting boxes with PC members which are firmly connected by compression joint method. Then by supporting these boxes by three independent columns, a "floating exhibition rooms" were realized. Those boxes with its frame style are adopting a number of details that no other example can offer.

This paper first introduces the design details followed by the problems raised during design stage, then reports the facts confirmed through our mockup tests and the field measurements.

\section{1. はじめに}

PC a P C圧着工法を用いた「組立箱構造」の建物の構造設計に ついて報告する。

用途は美術館で、建物の展示室空間を構成する壁・屋根・床すべ てをプレキャストコンクリート（以下PC a ）板とし、現場P C圧 着により「箱」を形成し、これを 3 本の独立柱で支えることにより、 「浮いた展示室」を実現させている。

$\mathrm{PC}$ a 壁は発泡断熱材を内蔵した 2 重殻構造とし、二重壁とする ことにより断熱性能に優れた展示室を、また、外側は全部で 80 万 枚の細かなタイルを打ち込んだ多種の曲面を連続させることによ り美術館建築にふさわしい特幑あるやわらかい外観形状を創り出 している。

この建物は、大断面の圧着工法によりそれ自身が構造体である 「箱」を組み立てたものであり、その架構形式と共に、特殊な多く のディテールを採っている。施工前に実大実験を行って課題を解決 し、実施工時には現場計測を行って設計の検証を行いながら施工を すすめた。

本報では、その設計内容を紹介した後、設計時の課題となつた事 項について、実大実験・現場計測を通じて解决した内容について報 告する。

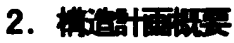

自然環境豊かな地に建ち、周辺の環境亡の調和か特に求められた この建物の設計に当たっては、それ自体が威王感を与えることなく、 自然の中にとけこませることを設計コンセプトとした。

1 階をオープンなエントランス空間とし、2階に各部屋ごとに展 示室を分棟配置し、それらを渡り廊下でなくごとにより、周囲の 自然を建物で分断しないようにしている。

\footnotetext{
*1 倈日建設計大阪本社 構造設計室長・工修

( 宁541-0043 大阪市中央区高麗橋4-6-2)

*2 株日建設計大阪本社 構造設計主管・工修

*3 㭌日建設計大阪本社 構造設計室修士(工学)
}

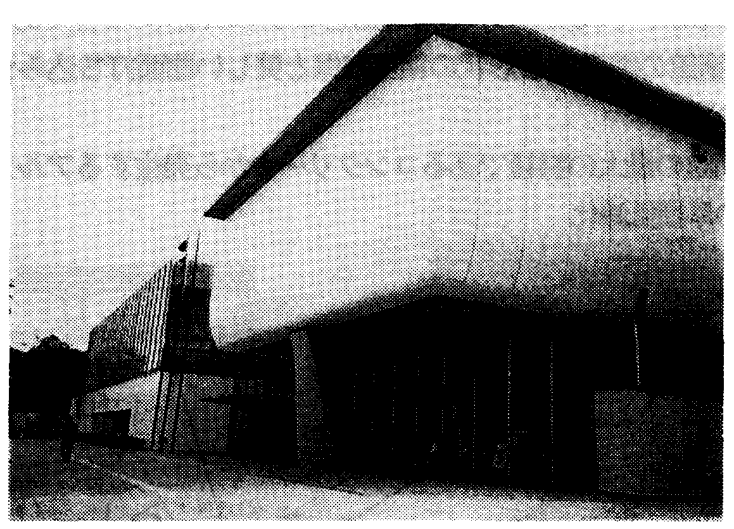

写真 1. 建物外観

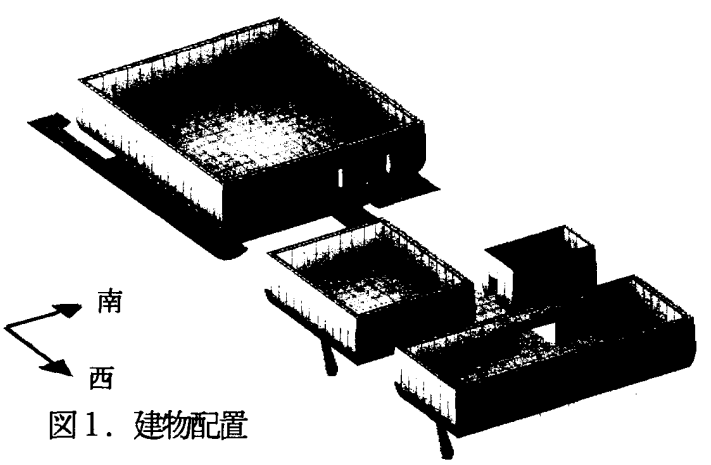

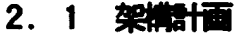

建物の 2 階に分棟配置した展示室のうち、正面の展示室の規模は、 平面の大きさが $21.8 \mathrm{~m} \times 18 \mathrm{~m}$ 、高さ $7 \mathrm{~m}$ である。展示室は機 能上四周を壁に囲まれた整形な形をしている「閉じた箱」である。 この「閉じた箱」を3本の独立した柱で支える計画とした。

*1 General Manager, Structural Engineering Dept., Nikken Sekkei Ltd., M. Eng.

*2 Senior Engineer, Structural Engineering Dept., Nikken Sekkei Ltd., M. Eng.

*3 Structural Engineering Dept., Nikken Sekkei Ltd., M. Eng. 
建物正面は、中央に柱が1本だけであるが 偏荷重に対しては、 箱全体が斿じれ抵抗し、後ろの2本の柱て踏ん張ることになる。 の立体効果により、3本の独立杜で支えた「閉じた箱」を安定した 構造としている。

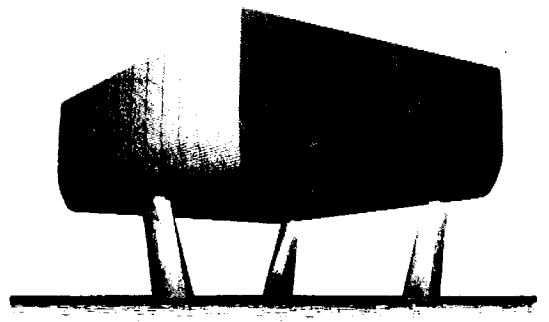

図2、「閉じた箱」

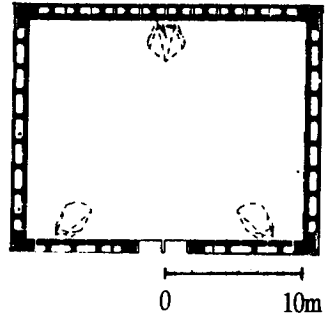

2 階展示室平面図

\section{2 PCa PC压江法}

この「箱」を構成する要素、つまり、床・壁・屋根すへてを工場 製作のプレキャストコンクリート板とし、現場にて組み立てるP C 压着工法を採った。部材は幅 $1.8 \mathrm{~m}$ をテテュールとした。

この工法を採った理由はP C構造の一般的な特徵である、工期の 短縮・現場作業の省力化・熱帯材型枠使用の抑制・躯体の高品質 化もあるが それ以上の大きな理由となったのは次の 2 点である。

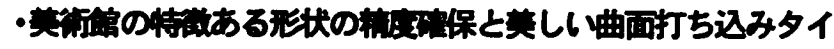 ル量の实現}

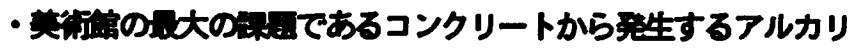
ガスの早期低化

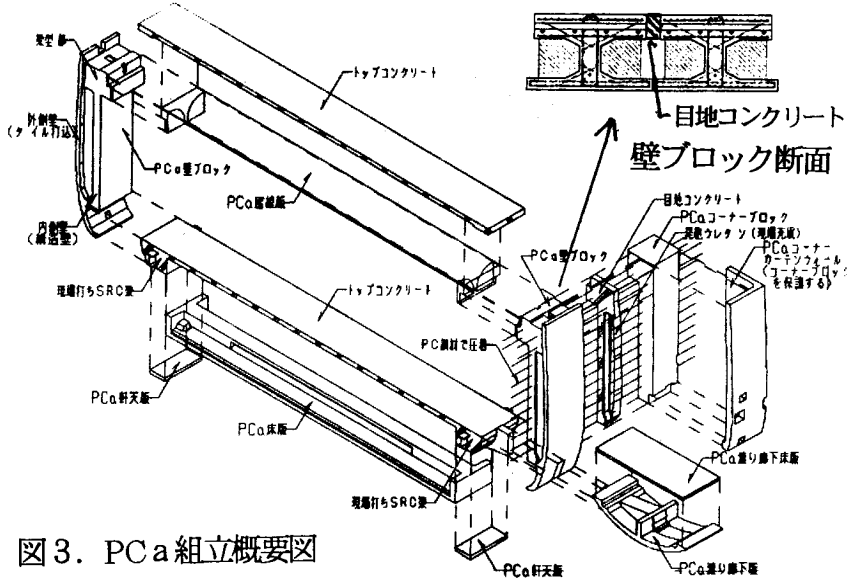

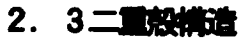

展示室内の環境は、外気によって変動することのない「恒温恒湿」 が求められる。このため、壁版を断熱材をサンドイッチした二重構

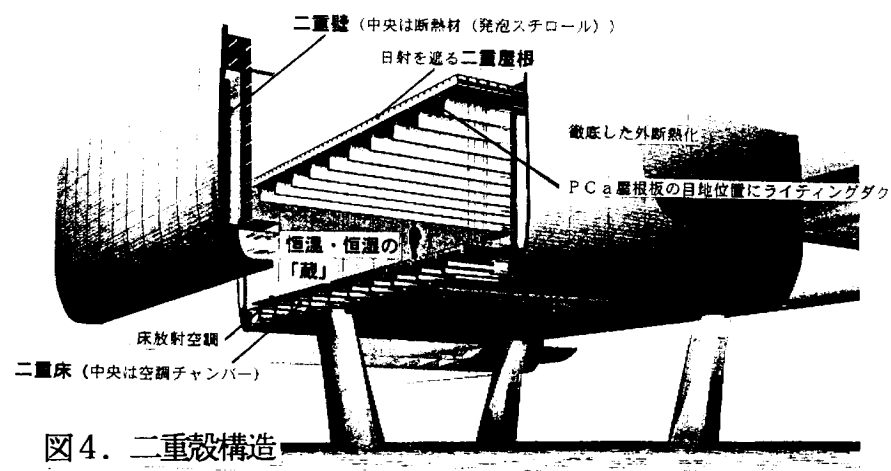

造板とし、いわゆる「蔵」のような環境となることを目指した。 イルか打ち込まれた丸みを持つ外壁之厚さ $350 \mathrm{~mm}$ の主構造て ある内壁の間に4 50 0 600 mmの断熱材 (発枹スチロール)を 内包した P C a 板とした。また、床を二重構造とし、その間の空間 を空調のチャンバーとして計画した。

二重壁・二重床とすることにより高断熱性と大きな熱容量を確保 し、非常に負荷がさく温度変動の小さい展示環境を実現した。

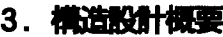

建物を特幑づける外周の壁板はディープビームとして、荷重を独 立柱に伝える。壁梁としての断面諸元を表 1 に示す。

「箱」の設計にあたっては、PC a 部材はフルプレストレスとなる ようにした。

$\mathrm{PC}$ a 壁ブロックは H 型断面の二重壁とし、内側の壁（350mm） を構造要素として横方向に緊張して圧着している（図3）。

外壁同士は接続せず、仕上げ材および面外方向の剛性を高めるの に寄与している。

「箱」を支える独立柱は現場築造のS $\mathrm{RC}$ 造である。箱の脚部に当たる 2 階外 周梁は現場打ちのS R C造として鉄骨で 独立柱と接続される。PC aによる壁・床 をSRC梁と圧着接合して「箱」を形成 している。(図5)

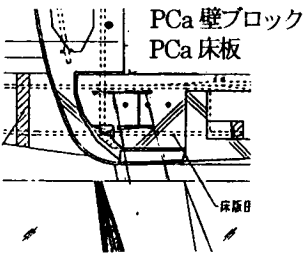

図 5. 断面詳細図
・設計用地震力の設定 ： 設計用地震力を 1 質点系弾性地震店答 解析を行うことにより設定した。建物の固有周期は X 方向で 0.34 秒、Y 方向で 0.35 秒である。各地震波は El Centro NS、Taft EW、 Hachinohe NS、JMAkobe NS の 4 波（最大速度：50 cm/sec）とす る。最大応答せん断力倸数が 1.38 (El Centro）であったため設計 用せん断力保数を 1.40 とした。

・耐震設計クライテリア： 設計用地震力として水平方向加速度 $1.4 \mathrm{G}$ が作用した場合、上下動による鉆值方向加速度 $1 \mathrm{Gが}$ 作用した 場合およびこれらを組み合わせた場合、また、上下方向逆対称ねじ れ何重を作用させた場合（西側+1G、東側一1G）に対して生じる 応力度が、(1)独立柱: 短期許容応力度以下 (弾性設計)、(2)各PC a 部材 : フルプレストレス、(3)P C 合成床の現場打ちスラフ部 : ひび 割れ応力度以下となるように計画した。

上記応答解析による応答加速度は最大で $1350 \mathrm{gal}$ となった。収容物 （絵画）は基本的には壁面に固定されていれい゙摇れに関しては問題 ないので、内装および什器の設計をこの加速度に基づいて行ってい る。

・解析手法 ： 全体架構を線材置換した立体架構モデルによる静 的解析および「箱」部分を立体モデル化した有限要素法解析

（NASTRANによる）を行い、長期荷重・偏し渮重・地震荷重（水 平・上下・逆刘称上下) に対する安全性を検証している。また、本 解析では「箱」のPC a 部材はこれらの荷動時にフルプレストレス となることを確認している。

図 7 に立体有限要素法解析結果（南・北壁面の応力）を示す。な お、プレストレス応力の算出にあたっては各ケーブルの設計導入緊 張力の最小值を外力として用いている。

有限要素法による解析結果によると、コーナ一部（北西・北東端 部）の長期荷重時の鈶直力向変位は $3.9 \mathrm{~mm}$ となっている。 
・ディテール設計

$\mathrm{PC}$ a 壁板の交点となるコーナーブロックは直交する 2 万们の緊張 端が交差する。2 方向から反力を受けるため複雑な応力を生じるが 断面を大きくして緊張時に生じる応力が許容引張応力度以下に ようにした。有限要素解析の結果を図6に示す。

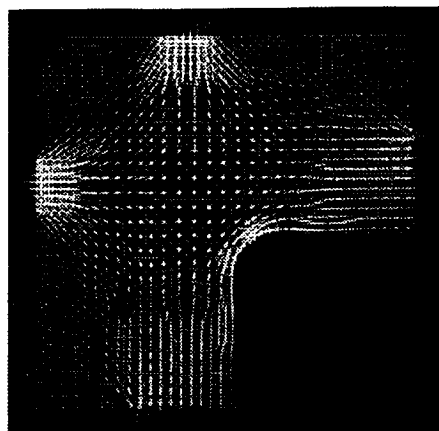

図6.コーナーブロック応力図

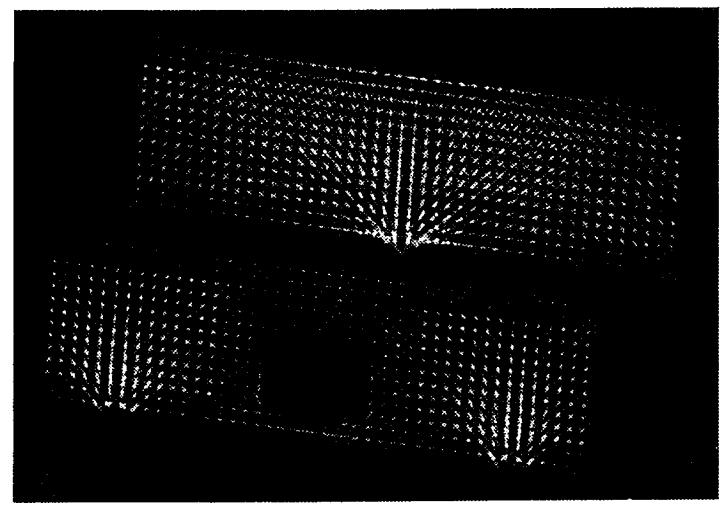

長期荷重時

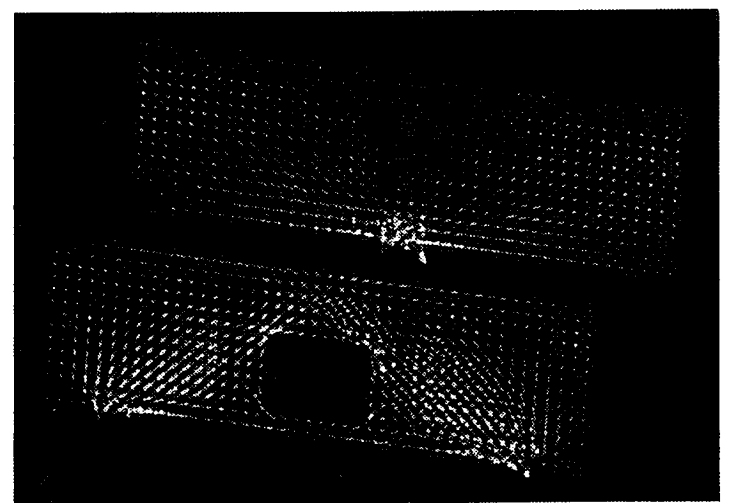

東西方向地震荷重時

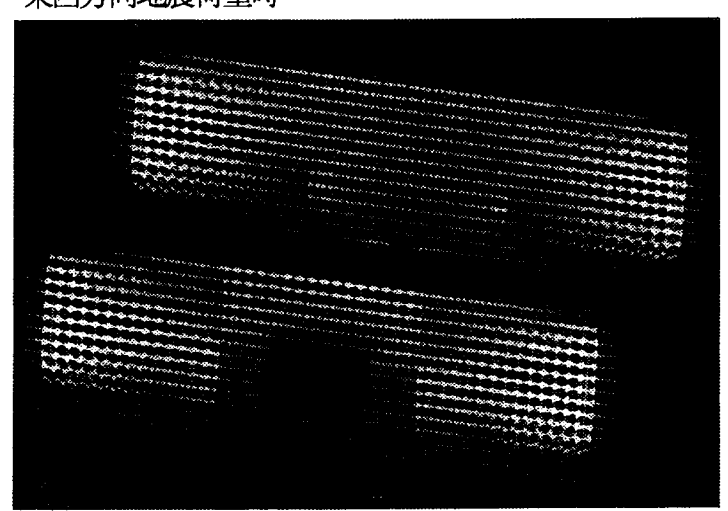

壁版P C 鋼線よこ緊張時（プレストレス応力）

図 7. 有限要素解析結果
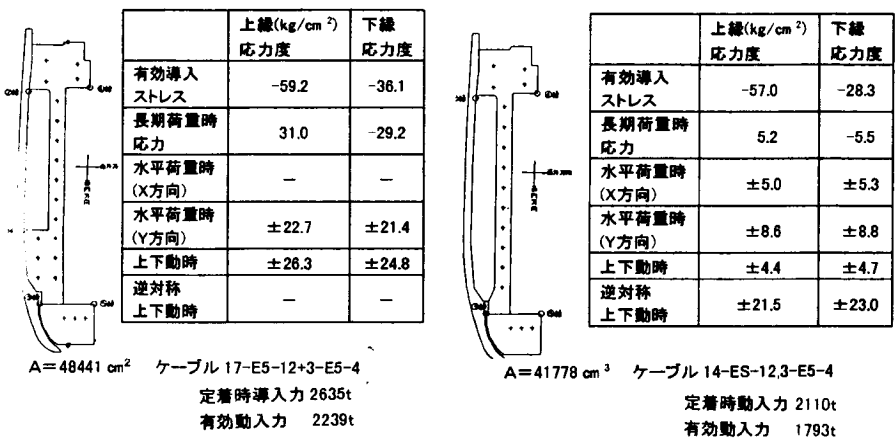

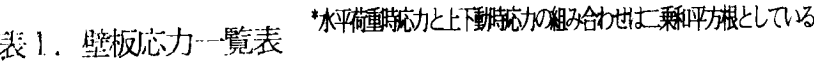

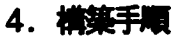

4. 1 架设

敷地南側の樹木を保護するために揚重は北側からのみとし、500 トン油圧クレーンにて架設した。組立順序は、以下の手順を採った。

1. 独立柱とそれに連続した外周鉄骨を組み立て、床板を敷き並 べる。

2. 外周 S R C 梁亡 P C 合成休のトップコンクリートを打設、緊 張する。(休の完成)

3. 幅 $1.8 \mathrm{~m}$ モジュールの壁板を床上に並へ壁を外周 S R C 梁 にたてに压着、その後壁間に目地コンクリートを打設し、壁 板相互をよこに压着する。（壁面の完成）

4. 屋根板を架設・トップコンクリート打設・緊張し、壁に圧着 する。(箱の完成)

5．最後に渡り廊下板を架設・王着する。

図8. 組立手順図

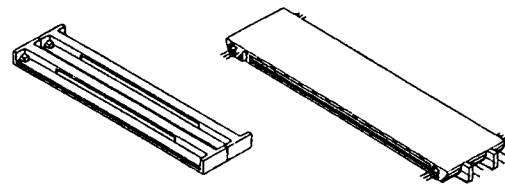

(1) 林版架設 (2) 林トッブコンクリート打設

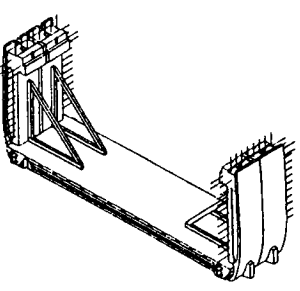

(3) 暨版架設

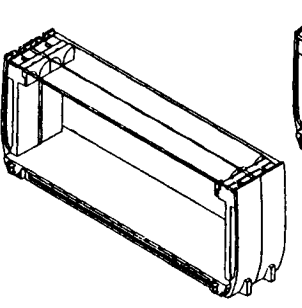

(4) 虽板版架設

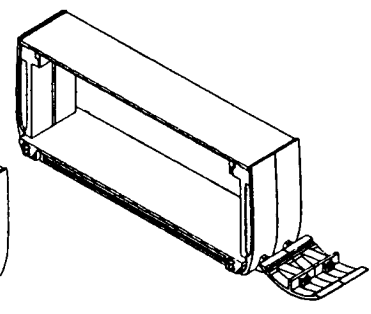

(5) 诉り值下版架設

\section{2 影㖘・グラウト}

プレストレストカは、先述したように設定したいかなる荷重時に も「箱」の各PCa部材はフルプレストとなるように計画した。

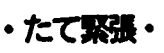

$\mathrm{PC} \mathrm{a}$ 壁板と休梁の压着は、壁板内に縦方向に4 $50 \mathrm{mmピッチ}$ で配したPC鋼棒 ( 32 \%) の緊張により行った。緊張力導入時に おける偏しを最小限にするため、部材の中心に配置したP C鋼棒か

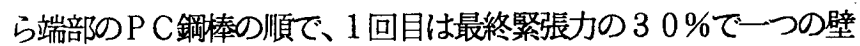
板の 4 本を緊張し、2回目に最終緊張力を同し順序で導入した。

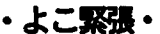

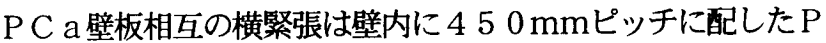
C鋼線により圧着し緊張力は2 $100 \mathrm{t}$ であるが、応力の集中する 独立柱の周辺は中空部をなくし、断面・緊張力を大きくしている。 
壁ブロックに均等に荷重を作用させるため、部材の中央部から上下 交互に、緊張を行った。

片引きで緊張を行うところは上から1本おきに緊張端・固定端を 左右交互にして導入力を左右均等になるようにした。

実大実験時、および実施工時にP C a 壁板・目地コンクリートに 歪みゲージを入れて導入力が断面に均等に作用していることを確 認しながら慎重に施工を進めていった。

\section{・スラブトップコンクリート籍・}

P C a 壁板・床板・屋根板の他、現場打ちである床・屋根のトッ プコンクリート面内も、格子状に緊張力を導入しているが ( $\mathrm{PC}$ 鋼

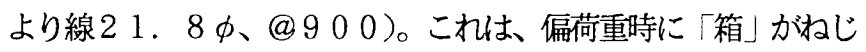
れることによって生じる面内せん断力に対処するためのものであ る。

\section{・グラウト・}

グラウト材は、低ブリージングタイプのグラウト材を、特に充填 性に注意の必要な水平 P C鋼材にはノンブリージングタイプのグ ラウト材を用い施工試験にて圧入速度と充填性を確認して施士に 臨んだ。グラウトは注入口の他に、必ず両側に排出口を設けて空気 だまりがないようにした。

本施工時には、流量計を用いてグラウト全数の注入量を管理して 慎重に施工を進めた。
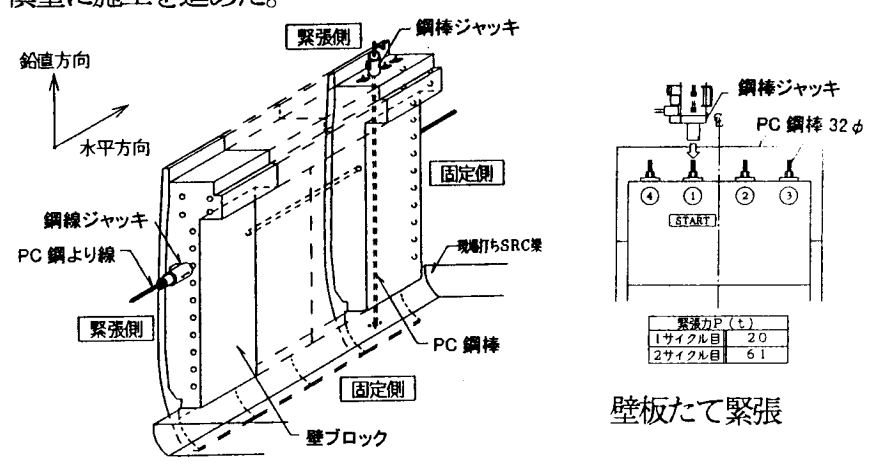

図9.緊張手順図
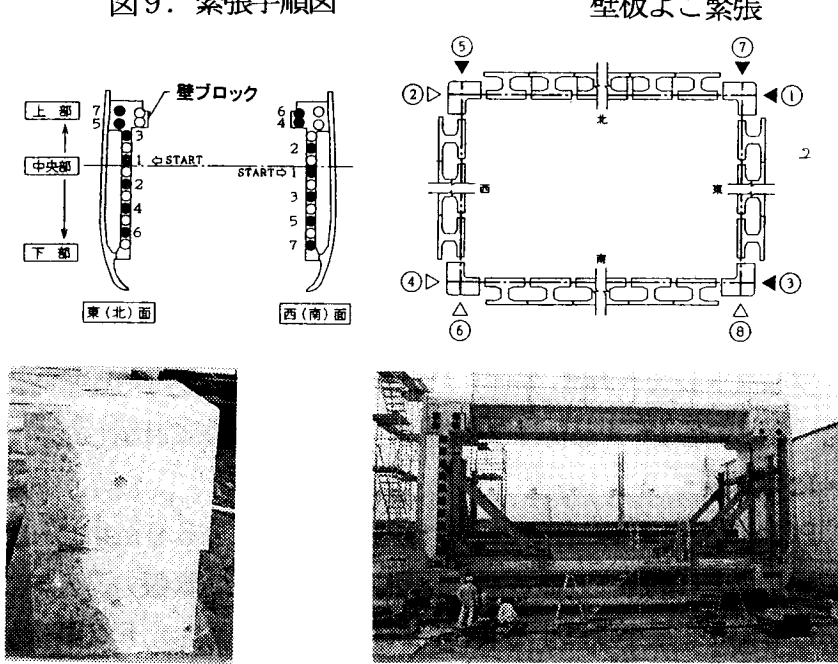

写真2．グラウト充填性確認試験 写真 3. 実大笑験状況

\section{5. 实大実唉}

P C圧着工法自体は、特殊技術ではないが、建物全体をブロック 圧着工法で構成した今回のような計画は類をみない。そこで、建物 の施工に着手する前に実大実験を行って、接合ディテールおよび組 立手順の施工性を確認した。
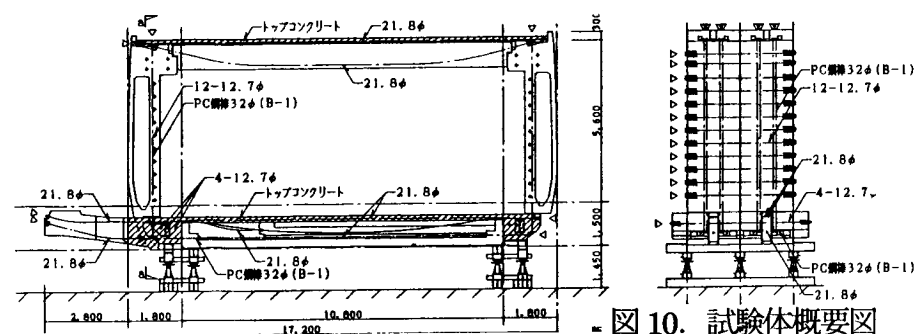

実験によって確認した主な事項を以下に示す。

・複雑な形状をした二重構造のP C a 壁板の製作法

・重量が大さタイル打ち込みで施工精度の要求される壁板の建 方方法、

・例を見ない大きな断面の圧着となる壁板と床、壁板どうしの接合 ディテール

・設計で想定した緊張力が各部に導入されてるか。

・グラウトの充填性を確保する方法

\section{1 部材些作}

建物を特幑づける幅 $1.8 \mathrm{~m}$ 、高さ $7.4 \mathrm{~m}$ 、重量約 20 トンの $\mathrm{PC} \mathrm{a}$ 壁板は、1 ピースで 2700 枚ものタイルを打ち込む、中央 に断熱材の発泡スチロールを打ち込んだH型形状の 2 重壁である。 その仕上がり・寸法精度には特に神経を使った。タイル打ち込み部 材における高周波バイブレーターの使用は、タイルのずれ、破損が 懸念されることから棒状バイブレーターのみの使用とし、施工性の 良い高流動コンクリートを用いた。この高流動コンクリートは普通 セメントとフライアッシュを用い、高性能A E 減水剂と堌粘剂粉末 を添加したスランプフロー值 $65 \mathrm{~cm}$ のものとした。これを専用バ ケットにて打設した（2．7 m 3 × 3 回)。さらに鋼製型枠に 10 фのエア一抜き穴を設けて、充填性の確保に努めた。鉄筋加工は先 組としタイルを敷き並へた型枠上に先組みした約 $2 \mathrm{t}$ の鉄筋をセ ットするが底盤に敷き並べたタイル上のスペーサーだけで受ける と夕イルの破損や剥離のおそれがあるのて鋼製型枠と一体となっ たフレームで先組鉄筋を吊り下げることにより重量を支えるよう にした。

また、打ち込みの発歾スチロールがコンクリート打設による浮力 で移動しないよう、㑡面の鋼製型枠からのセパレーターと上部から の金物により固定した。

$\mathrm{AE}$ 減水材を用いるコンクリートに蒸気養生を行うと熱膨㖘によ り組織扡緩を生じる獎念もあるので（＊2）、蒸気は用いるものの、 最高温度は $35^{\circ} \mathrm{C}$ し、夏場の雲囲気温度にて養生することとした
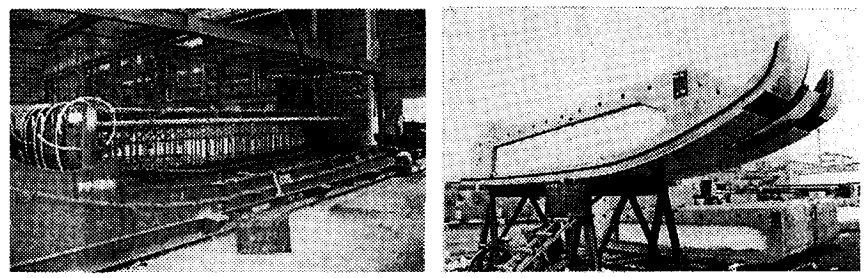

写真4. 壁板製作状況

\begin{tabular}{|c|c|c|c|c|c|c|}
\hline \multirow{2}{*}{ セメント } & \multirow{2}{*}{ 水 } & \multirow{2}{*}{ 海林 } & \multirow{2}{*}{ 看材 } & \multicolumn{2}{|c|}{ 湦和剂 } & \multirow{2}{*}{$7317, \dot{1} 2$} \\
\hline & & & & SP8N & 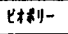 & \\
\hline 430 & 165 & 820 & 909 & 6.5 & 0.5 & 70 \\
\hline 水セメント比 & $33.0 \%$ & \multirow{2}{*}{\multicolumn{5}{|c|}{$36-65-20 \mathrm{~N}$}} \\
\hline 期保林韧 & $51.3 \%$ & & & & & \\
\hline
\end{tabular}

表 2 。高流動コンクリート配合 


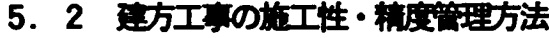

$\mathrm{PC}$ a壁板は高さ $7 \mathrm{~m}$ 、重さ $20 \mathrm{t}$ を超える大型ピースであり、 またタイル打ち込みでそれ自体力外壁となる構造体であるため、 厳しい建て方精度が必要である。詿験部材を用いた建方実験を行い， 各部材の 4 隅を 3 次元測定システムMONMOSにより湘定し、建 入れ精度管理方法の確認を行った。

架設は壁板朋部両側に取り付けたレベル調整用ボルトと転倒防 止・建入れ調整の目的て設置した仮設バットレスから押し引きボル トにより微調整を行った。実際の目線に近い下側を基準にして架設 することにより、外観上問題のない精度で施工することか可能であ ることを確認した。匡着面に確実に緊張力力導入されるように、レ ベル調整用ボルトは壁ブロック下端の水平目地強度発現後に切断

した。

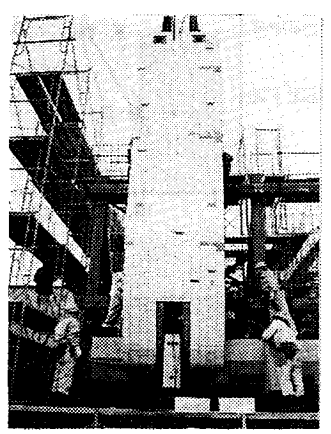

写真4.壁板建方試験状况

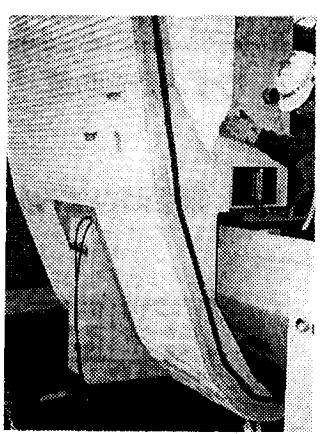

\section{3 水平目地施工性・充犊栍}

壁ブロック下端と S R C 梁之の水平目地は、幅 $1800 \mathrm{~mm}$ 、奥 行 $500 \mathrm{~mm}$ の扁平な空間であり、目地材の確実な充填か可能な施 工法を確立するため、注入材料（無収縮モルタル、PCグラウト）、 注入方法 (閉鎖型、開放型) および目地厚をパラメーターとして、 透明なアクリル板を用いた試験体を製作して、注入試験を実施した、

材料については、PCグラウトの方が流動性があり、施工性が良 かったが 強度発現が早く、から強度值力安定している無收縮モル タルを採用することとし、確実な注入作業を行うため、注入速度を 管理することとした。目地厚については、大きすぎると空気を押し 出しきれずに内部に残留し空隙を生じる傾向があり、小さいと流動 性が悪くなる傾向が見られた。最適な目地厚として $30 \mathrm{~mm}$ と設定 した。注入方法については、開放型か㳘填性に優れており、注入状 況の確郡がおこなえるため、開放型とすることとした。

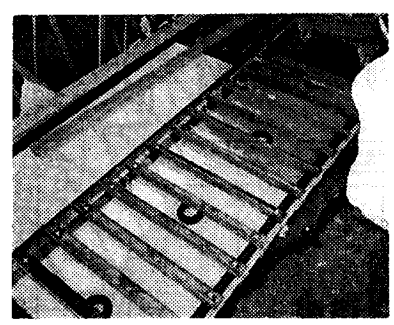

写真 5. 水平目地充填確䛱誻式験

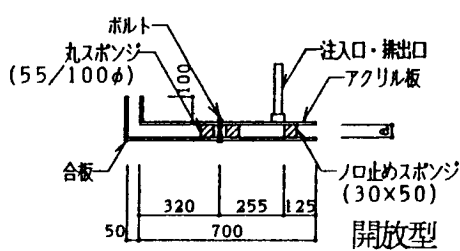

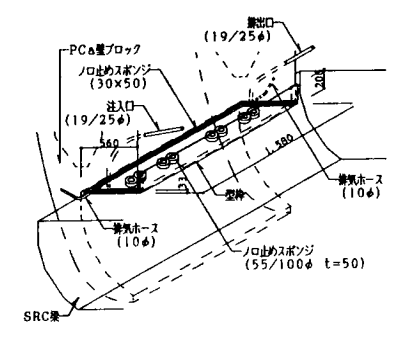

図 11. 水平目地詳細

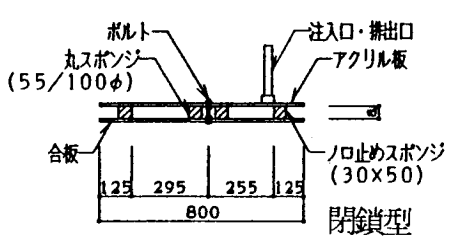

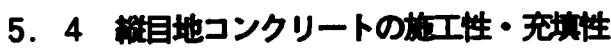

壁ブロック誵目地は高さ 6000 $\mathrm{mm}$ 、奥行き $350 \mathrm{~mm}$ 、幅 220 $\mathrm{mm}$ の細長い空間である。この空間 には水平シース、鉄筋が混在して配 置されることから、材料分離を生じ ず密実なコンクリートを打設するた め高流動コンクリート（F c 360 $\left.\mathrm{kg} / \mathrm{cm}^{2}\right)$ を用い目地の高さ $3 \mathrm{~m}$ 程 度まではトレミ一管 $(90 \phi)$ を挿 入して打設した後、トレミ一管を引 き拔き電動ホッパーで上部から残り の部分を打設する方法を採用した。 施工に先立ち、実大の試験体を作成 して充填性を確認したが、材料分離 を生じない密実なコンクリートが打

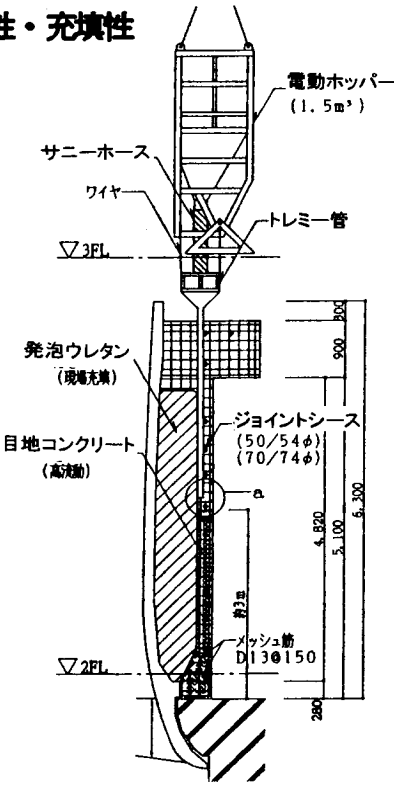
設されていることを確認した。

\section{6. 歪・たわみ计相}

この建物は壁・床・屋根などの $\mathrm{PC} \mathrm{a}$ 構造部材を緊張材で圧着す ることによって成立する構造であるので、緊張管理が特に重要であ る。先に述べた実大実験において緊張力の導入によって各部材に生 じているひずみを調べ、緊張手順の確認、緊張力の管理や変位の計 測と建て方のシミュレーションを行った。その後、約 9 ケ間にわ たって長期計測を行っている。

また、実施工時に、工事の施工各段階で各部材のひずみとたわみ を計測し、設計值の検証をおこなった。

ここでは、壁ブロックを圧着する壁板よこ緊張を中心に述べる。

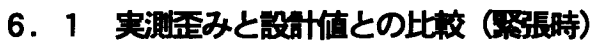

実施工時に建物中央の独立柱位置で計測したの圧着部ひずみ（壁 板に埋設したひずみ計の值)を図 15 に示す。この位置では、ひず み計を圧着部の両側の壁板それぞれの上部、中央、下部、計6点に とりつけ、計測している。緊張時のひずみの計算值との比較を図 1 6 に示す。

比較の際に用いたヤング係数は、緊張時に測定したテストピース 試駼結果の值を用いた。

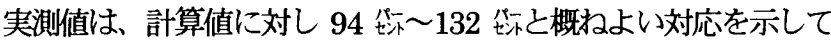
いる。実測值で歪み分布が中央部でやや大きくなっているのは平面 保持を仮定できるまで歪みが分散していないためと考えられる。

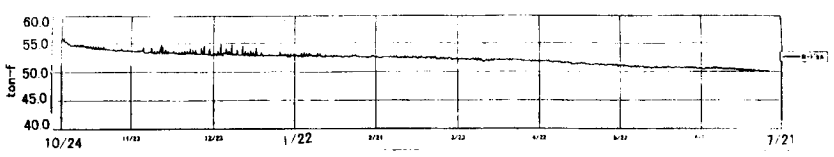

図 13. 鋼棒張力（長期）

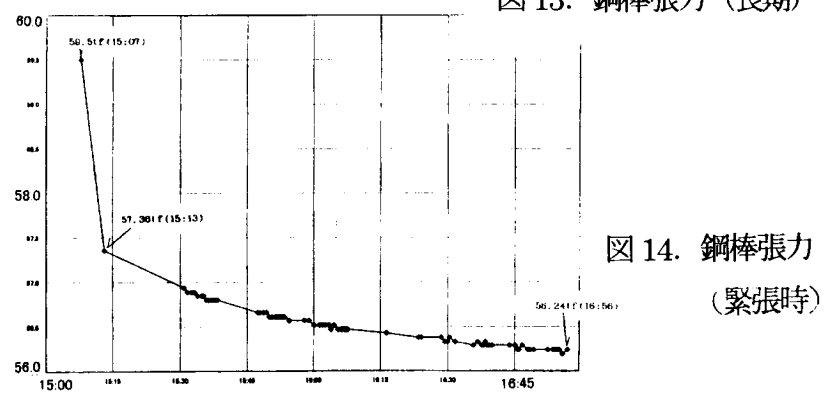


図7に示す有限要素解析では、緊張端付近では緊張部の歪み分布で あるが中央部ではほぼ平面保持を仮定できる歪み分布をしている。

大断面部材の緊張に際しては、断面内の応力の広がりを考慮する ことが大変重要であることがわかる。

\section{2 支保工解体時の歪み・たわみ}

支保工解体時のコーナ一部のたわみは東西両端とも約 $2 \mathrm{~mm}$ であ り、解析值 (3. $9 \mathrm{~mm})$ の半分程度であった。

壁板の歪みにも変化が見られたが上部で $20 \mu$ 引っ張り側へ移行 したのみで計算值 $(62 \mu)$ を下回った。

元々たわみ量が小さいので支保工設置中に躯体に荷重が作用して いたと考えられる。

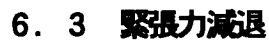

実大実験で計測した横緊張による壁板横方向の歪み計測結果を図 19 に示す。最終計貺時（PC 緊镸時より 9 ヶ月）の歪みのクリー プ保数は 0.4 0.7（PC 規淮による計算值：1.4）であった。

また、たて緊張において、3 2 中 P C鋼棒のうち 1 本の固定側につ いては、緊張力の减退を長期間にわたって確認する目的でロードセ ルを残した。図 1 3、14に緊張力の推移を示す。最終計貺時 (PC 緊張時より9ケ月）の歪みのクリープ係数は 1.24 (PC 規準による 計算値 : 1.4) であった。

\section{4 セットロス}

壁板横緊張時に計測したP C 鋼線（VSL 工法全 449 本）のセッ トロスは $2 \mathrm{~mm} \sim 8 \mathrm{~mm}$ で平均值は $4.7 \mathrm{~mm}$ (設計值 : $6.0 \mathrm{~mm}$ ) であった (図 20 )。

また、たて緊張時の鋼棒の荷重を見ると (図 $13 ， 14$ )、定着前 の5 9. 5 t o nに対して、緊張直後において 56.2 t on (9 4. 5唯) までの减少があったことがわかる。

これをセットによる戻り量とすると $0.3 \mathrm{~mm}$ 戻りが生じたこ とになる。鋼棒であっても支圧板の変形、鋼棒ねじ部のガ夕等によ り懄な戻りが生ずると思われるが短い鋼棒では緊張力のロスは設 計上無視できない值となる。この建物の実施工時には上記口スを見 込んで導入力を增し、定着完了時の必要導入力を確保するようにし た。

\section{5 まとめ}

長期計測を通じて、緊張による応力・歪みは設計時点での想定值 を満足するものとなったことを確認した。この他、大断面部材では 断面内の応力の広がりを考虑する必要があること、鋼棒でもセット による戻りを考慮する必要があること等、設計上の注意点を確認し た。

\section{7. 桻わりに}

この建物は、PC a 大断面部材の圧着工法によりそれ自身が構造体 である「箱」を組み立てるものである。架構の考え方、ディテール は例を見ないものがあり、設計時の課題も多くあった。設計・施工 に当たっては、解析・実大実験・現場計測を通じて、課題を解决し ながら進めていった。

実現にあたり、施工に際しての課題は技術プロジェクトチームを 結成して、実験・施工に臨んでいる。監督員としてプロジェクト全 体にわたり御助言・御理解をたまわった愛媛県の皆様、共に知恵を 出し合い、御協力を頂いた大成・野間共同企業体、大成建設（株） 技術開発本部、及び（株）ピー・エスの皆様に深く感謝の意を表し

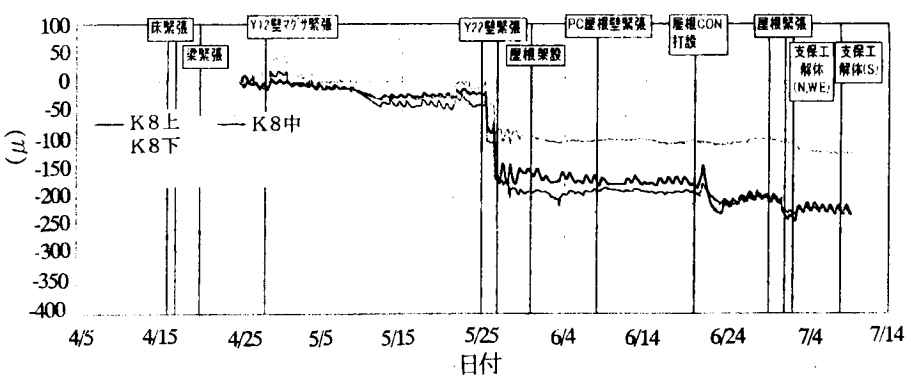

図 15. 独立柱位置圧着部ひずみ計測結果

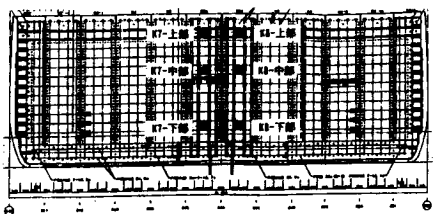

図17。ひずタ計測位置

図16.緊張時ひずみ分布
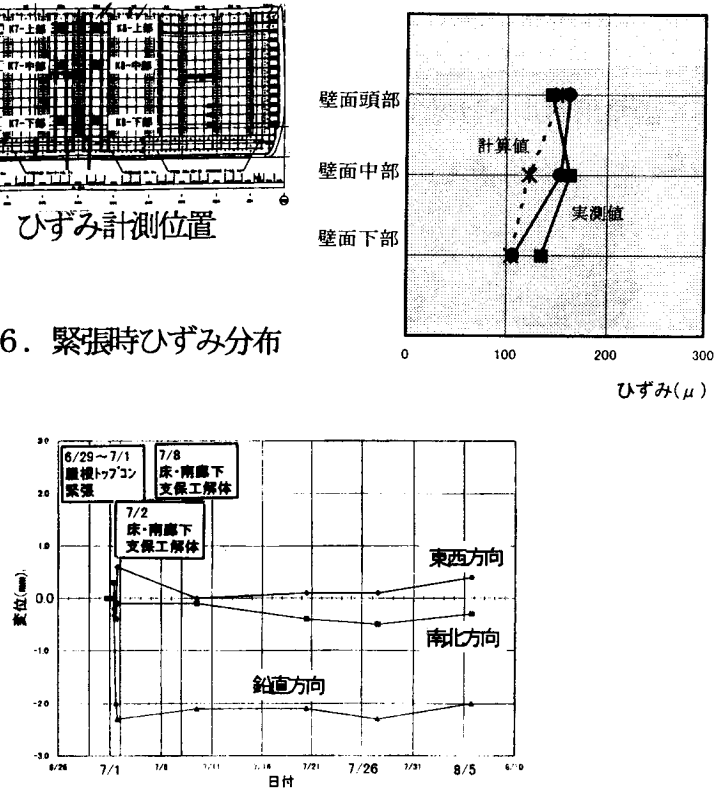

図 18 . コ一ナ一部変位（支保工解体時）

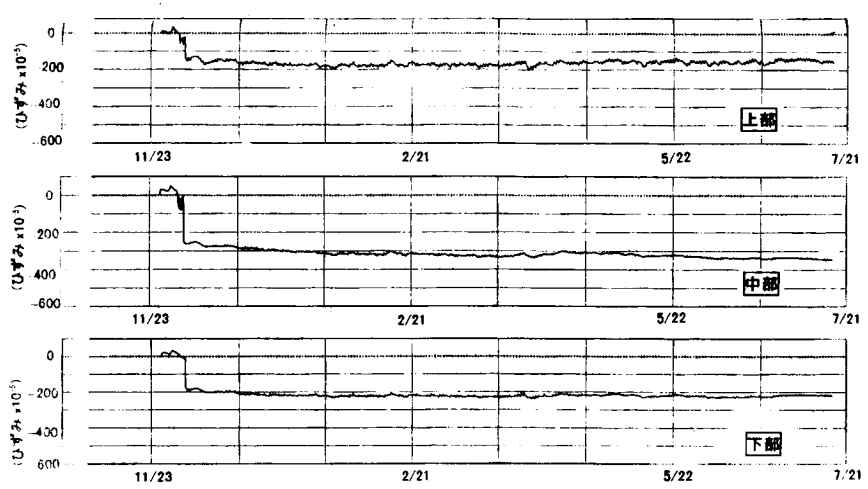

図19.実大実験ひずみ計測結果

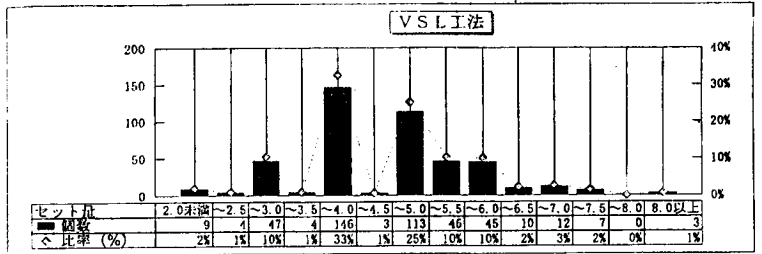

図 20.セットロス值集計結果

ます。

(参考文献（*1) プレストレストコンクリート設計施工規準・同解説 (日本建栄学会)

（*2）建勧工事慓淮仕様書・同解説 J ASS 10 (日本建築学会)

(*3) 建築工事摽准仕样書・同船説 J ASS 5 (日本建学会)

[1999年 4 月20日原稿受理１999年 7 月27日採用決定］ 